\title{
The challenge of abandonment for the sustainable management of Palaearctic natural and semi-natural grasslands
}

\author{
Orsolya Valkó', Stephen Venn ${ }^{2,3}$, Michał Żmihorski ${ }^{4}$, Idoia Biurrun ${ }^{5}$, \\ Rocco Labadessa ${ }^{6}$ \& Jacqueline Loos $^{7}$
}

Keywords: cessation, disturbance, diversity, fire, grazing, land use, mowing, sustainability.

Ključne besede: opuščanje, motnja, raznolikost, ogenj, paša, raba tal, košnja, trajnost.
Received: 30.1 .2017

Accepted: 30. 1. 2017

\begin{abstract}
Disturbance by biomass removal is a crucial mechanism maintaining the diversity of Palaearctic grasslands, which are unique biodiversity hotspots. The century-long traditional land use of mowing, grazing and burning, has been fundamentally changed in many parts of the Palaearctic. Due to socio-economic changes, large areas of former pastures and meadows have been abandoned, leading to a succession towards secondary scrublands or forest and the encroachment of competitor grass species, all leading to a decrease in biodiversity. Here we report the causes and consequences of the cessation of traditional grassland management regimes, provide strategies for reducing the impact of abandonment and consider these from the perspective of sustainability. We consider the possibilities for initiating sustainable management regimes in the contemporary socio-economic environment, and discuss the prospects and limitation of alternative management regimes in the conservation of grassland biodiversity. These themes are also the core topics of this Special Feature, edited by the EDGG. We hope that this Special Feature will encourage steps towards more sustainable strategies for the conservation of Palaearctic grasslands and the integration of the sustainability perspective into their conservation.
\end{abstract}

\section{Izvleček}

Odstranjevanje biomase je motnja, ki predstavlja ključni mehanizem za vzdrževanje raznolikosti palearktičnih travišč, ki so edinstvene vroče točke biodiverzitete. Stoletna tradicionalna raba tal s košnjo, pašo in požiganjem se je drastično spremenila v mnogih predelih Palearktike. Zaradi socio-ekonomskih sprememb je prišlo do opuščanja velikih površin nekdanjih pašnikov in košenic, ki se s sukcesijskimi spremembami spreminjajo $\mathrm{v}$ grmišča in gozdove ali se zaraščajo z bolj konkurenčnimi travami, vse pa se odraža $\mathrm{v}$ zmanjšani biodiverziteti. $\mathrm{V}$ člankih poročamo o vzrokih in posledicah prenehanja tradicionalnega gospodarjenja s travišči, predlagamo strategije za zmanjšanje učinka opuščanja in jih obravnavamo z vidika trajnosti. Zato predlagamo možnosti za trajnostno gospodarjenje v sodobnem socio-ekonomskem okolju in razpravljamo o možnostih in omejitvah drugačnih načinov upravljanja pri ohranjanju biotske raznovrstnosti travišč. To je tudi osrednja tematika posebne številke, ki smo jo uredili člani EDGG. Upamo, da bo ta posebna številka omogočila nadaljnje korake $\mathrm{k}$ bolj trajnostnim strategijam za ohranjanje palearktičnih travišč in vključevanje trajnostnega vidika pri njihovem ohranjanju.

1 MTA-DE Biodiversity and Ecosystem Services Research Group, Egyetem sqr. 1, H-4032, Debrecen, Hungary. E-mail: valkoorsi@gmail.com

2 Ecosystems and Environment Research Programme, Faculty of Biological and Environmental Sciences, University of Helsinki, P.O. Box 65 (Viikinkaari 2a), 00014, Finland. E-mail: stephen.venn@helsinki.fi

3 Department of Architecture, Aalto University, P.O. Box 16500 (Miestentie 3), 00076 Aalto, Finland

4 Institute of Nature Conservation, Polish Academy of Sciences, Mickiewicza 33, 31-120 Kraków, Poland. E-mail: michal.zmihorski@gmail.com

5 Department of Plant Biology and Ecology, University of the Basque Country UPV/EHU, Apdo. 644 E-48080 Bilbao, Spain. E-mail: idoia.biurrun@ehu.es

6 Association Centro Studi de Romita, Via G. Postiglione 9, c/o Filippo D’Erasmo, 70126 Bari, Italy. E-mail: rocco.labadessa@gmail.com

7 Agroecology, Department of Crop Science, Georg-August University. Grisebachstrasse 6, 37077 Göttingen, Germany. E-mail: jloos@gwdg.de 


\section{The challenge of abandonment for sustainable grassland management}

\section{Role of disturbance in maintaining species-rich grasslands}

Disturbance by biomass removal plays a central role in maintaining the open landscape structure and biodiversity of grasslands (MacDougall \& Turkington 2007, Tälle et al. 2016). Halada et al. (2011) identified a total of 63 European habitat types of community interest (European Commission 1992) that depend on low-intensity agricultural practices by grazing or mowing. This is especially true in the case of semi-natural grasslands, which have been created and maintained by century-long human land use (Pykäla 2001, Dengler et al. 2014, Leuschner \& Ellenberg 2017). Anthropogenic use of grasslands dates back to the Copper Age in Europe, when wetland grazing started in approximately 3800 BC (Bakker 1998). From this period onwards, forest opening and the creation of pastures spread throughout Europe (Poschlod \& Wallis
DeVries 2002, Dengler et al. 2014). According to the intermediate disturbance hypothesis (Connell 1978), the diversity of grasslands is highest at intermediate levels of biomass removal (Kelemen et al. 2013). In the absence of anthropogenic biomass removal regimes, natural disturbance by windstorms, wildfires and the grazing of wild herbivores (game, rodents and invertebrates) have an important role in maintaining diversity, especially in natural grasslands. However, in semi-natural grasslands they cannot mitigate the negative consequences of abandonment, since the frequency and severity of these disturbances are low and unpredictable, compared to anthropogenic biomass removal through mowing, grazing or burning.

\section{Effects of abandonment}

Litter accumulation is an important primary consequence of the cessation of grassland management. Depending on the grassland type, abandoned grasslands are characterised by considerably higher litter values. Litter accumulation is highest in moist, high-productivity sites. Valkó et al. (2012) found a two-fold increase of litter in mesophilous meadows and a threefold increase in wet meadows after fifteen years of abandonment. The accumulated litter layer acts as a seed trap, which prevents the germination and seedling establishment of light-de-

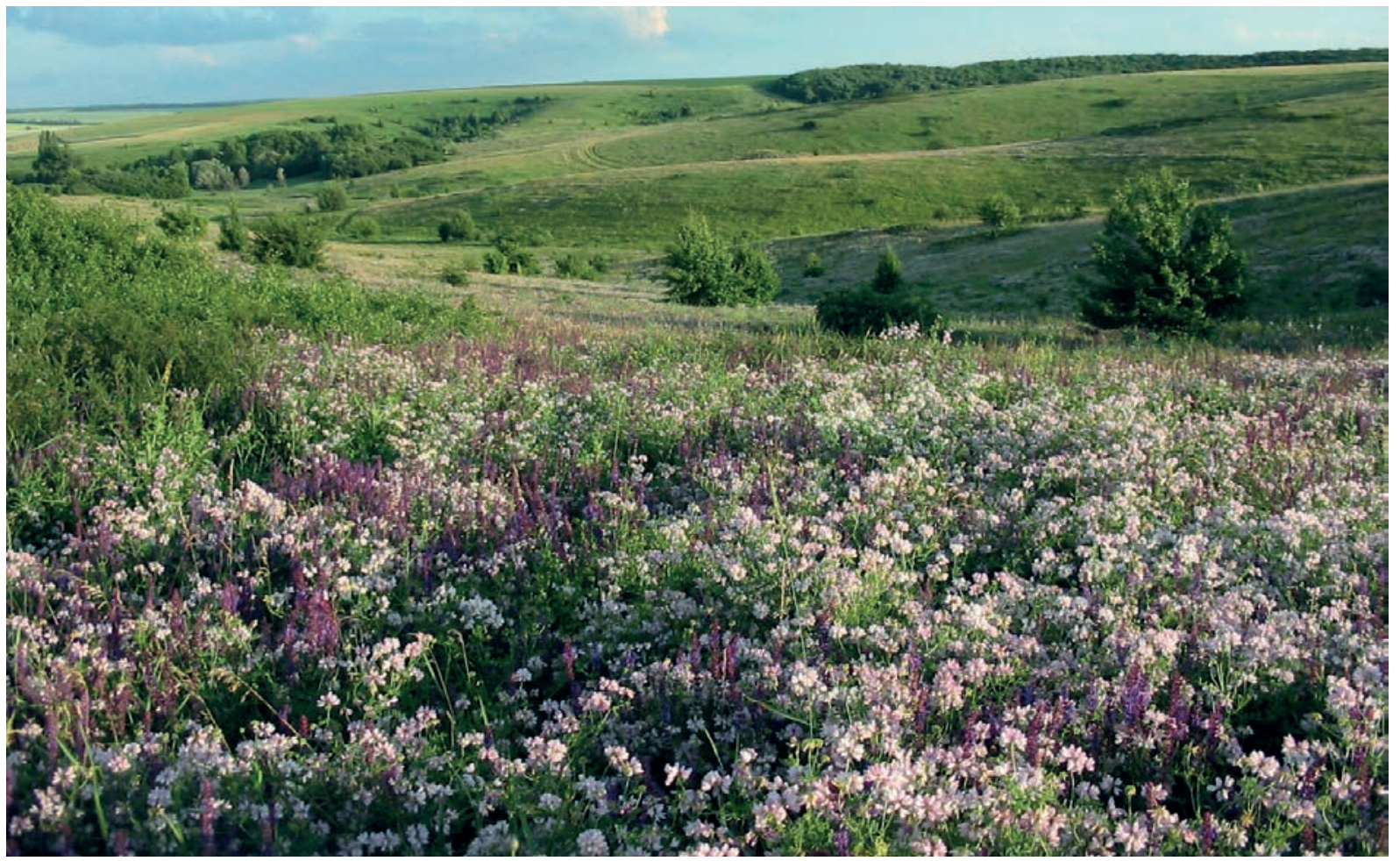

Abandoned gullies in Veliky Burluk Steppe, Ukraine. Photo by Vladimir Ronkin.

Opuščeni jarki v stepi Veliky Burluk, Ukrajina. Foto Vladimir Ronkin. 


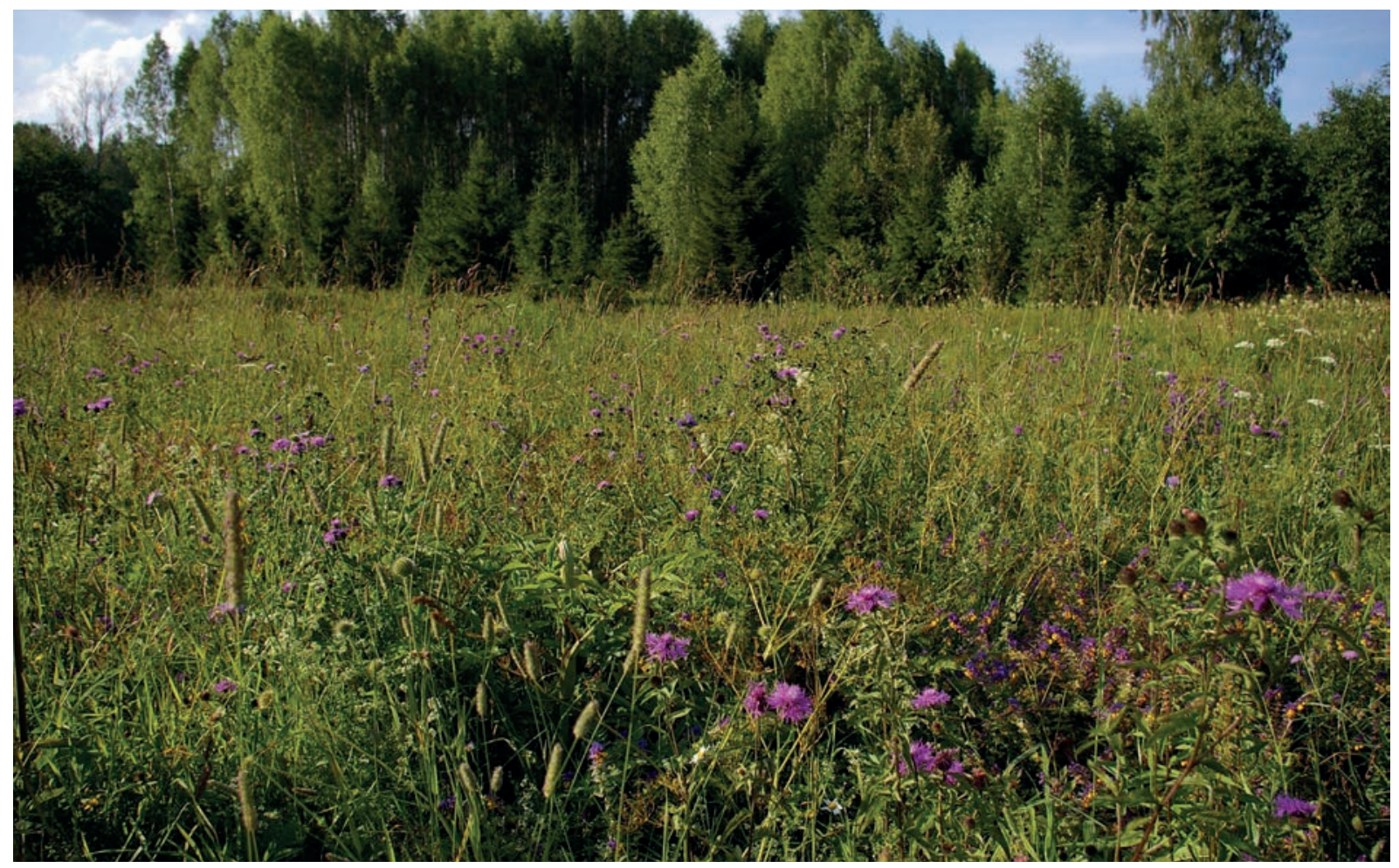

Abandoned mesic meadows with dominance of Centaurea phrygia, Dactylis glomerata and Melampyrum nemorosum in the Central Forest Reserve, Northwest Russia. They were used for hay making before the early 90's, since that time they have been abandoned. Photo by Valentina Borodulina. Opuščeni mezofilni travniki s prevladujočimi vrstami Centaurea phrygia, Dactylis glomerata in Melampyrum nemorosum v Centralnem gozdnem rezervatu v severozahodni Rusiji. V začetku devetdesetih so jih uporabljali za seno, od takrat pa so opuščeni. Foto Valentina Borodulina.

manding seeds of grassland specialist species (Eckstein \& Donath 2005, Deák et al. 2011). Decreased light availability on the soil surface and allelopathic compounds in litter, further prevent the chance of germination (Diemer et al. 2001, Bonanomi et al. 2006). Decreased microhabitat availability generally leads to homogenisation of the species composition, and to the encroachment of a small number of competitor grass species, at the expense of grassland specialist species (Gazol et al. 2014, Köhler et al. 2005, Valkó et al. 2016a). The resultant higher sward and less palatable vegetation do not provide all the habitat functions for grassland specialist animal species (Öckinger et al. 2006). Keystone species, such as grassland rodents, can be seriously affected by abandonment (as shown for Steppe Marmot by Savchenko \& Ronkin 2018, this issue), which can have cascading effects on the whole ecosystem. Accumulated litter also constitutes fuel, which can lead to increased fire risk and occasionally catastrophic wildfires (Deák et al. 2014, Brinkert et al. 2016). Grassland management often creates and maintains the relationship between otherwise unconnected grassland sites, e.g. by the dispersal of seeds and vegetative propagules between sites (Auffret 2011). Abandonment of livestock grazing therefore leads to drastic changes in seed dispersal patterns (Brinkert et al. 2016) and in the metapopulation structure of grassland specialist plants, with some delay due to extinction debt (Helm et al. 2006, Kuussari et al. 2009, Cousins 2009).

Abandonment can lead to the complete disappearance of grassland vegetation after as little as 20 years if they are overgrown by forests (Hansson \& Fogelfors 2000). Woodland encroachment is a major threat, especially in the boreal and forest-steppe zones, and in high-productivity sites, where woody vegetation can establish rapidly. For instance, a critical proportion (59-94\%) of speciesrich alvar grasslands in Estonia have been overgrown by scrubland or forest (Helm et al. 2006). Woodland encroachment was also the strongest driver in unmanaged loess grassland fragments in Hungary (Deák et al. 2016a). Woodland encroachment leads to the temporal or permanent disappearance of a habitat with high conservation value, and also to the termination of traditional land use and a potential source of income for local people. Habitats that develop after the abandonment of grasslands represent lower biodiversity and aesthetic values, and are generally not favourable for agriculture, often because of their remote location on slopes and hills, which are difficult to access. 


\section{Causes and degree of abandonment}

Agricultural intensification and urbanisation have directly caused an increasing depopulation of rural areas in several regions of Europe (Halada et al. 2017, Balázsi 2018, this issue), which has led to the abandonment of many traditionally managed agricultural areas (Gracheva et al. 2018, this issue). In Western Europe, early urbanisation, industrialisation and agricultural intensification have caused reductions in the cover of traditionally managed grasslands to a small fraction of their former extent (Kovács-Hostyánszki et al. 2016, Janssen et al. 2016). In the former COMECON countries of Central and Eastern Europe, the socio-economic switch from collectivisation to a market economy has led to substantial changes in grassland management (Isselstein et al. 2005, Balázsi 2018, this issue). This comprises a change from extensive to intensive animal husbandry, and the increasing preference for arable forage crops instead of hay (Kovács-Hostyánszki et al. 2016). As a consequence, extensively grazing livestock numbers have generally decreased by more than $50 \%$ up to $70 \%$ since 1989 (Isselstein et al. 2005). In Asia, large areas of formerly grazed steppe have been abandoned due to the sedentarisation of nomadic farming systems and the intense poaching of wild megaherbivores (Kamp et al. 2016).

The areas that are most vulnerable to the effects of abandonment include those that are (i) isolated and difficult to access (Valkó et al. 2011), (ii) small, fragmented and embedded in a non-grassland matrix (Deák et al. 2016a,b) and (iii) large and remote (Brinkert et al. 2016, Deák et al. 2018). In such areas, traditional grassland management becomes unfeasible and unprofitable in many cases, thus it does not seem economically viable any more.

\section{What management regimes are necessary to maintain grassland biodiversity?}

Given the huge number of abandoned grasslands and the limited amount of available financial sources, only a small proportion of the abandoned grassland area can be restored under current strategies. Grassland species usually do not have long-term persistent seed banks (Valkó et al. 2011), thus increasing time since abandonment decreases the potential for spontaneous recovery (Cherednichenko \& Borodulina 2018, this issue) and increases the costs of restoration. From this perspective, the restoration prospects of recently abandoned grasslands are more promising (Bekker et al. 1997). This is especially true for sites affected by woodland encroachment, which considerably increases the costs of restoration.
For mitigating the effects of abandonment, the reintroduction of traditional management regimes on a large scale would be the ideal solution from the ecological perspective (Valkó et al. 2011). Traditional management regimes have not been comprehensively documented in many cases, thus interviews with local farmers and knowledge of site history and traditional and local ecological knowledge are important tools which can support conservation projects (Babai \& Molnár 2014). For identifying the best management options, we should also consider and harmonise the requirements of multiple taxa (WallisDeVries et al. 2002). When choosing the appropriate method for managing grasslands, site managers generally choose between the two options of grazing and mowing (Tälle et al. 2016). These measures should be fine-tuned in terms of timing of mowing (Humbert et al. 2012), mowing frequency (Ryser et al. 1995), type of biomass removal (i.e. type of mowing machinery, Parr \& Way 1998, Humbert et al. 2009, Tälle et al. 2014, or type of grazing animal, Tóth et al. 2016). In order to successfully bring about the reintroduction of traditional methods, it is essential to ensure that they are economically viable and socially rewarding for the farmer, which currently they are not.

\section{Is the ideal method feasible in the specific socio-economic environment?}

After identifying the most proper management regime, there is still the question of whether this regime is feasible in a certain socio-economic environment. Presence of mowing machinery or livestock is an important prerequisite for management. However, for the sake of cost-effectiveness, it is also important to have the potential to support the livelihood of local people with local animal husbandry and support the market with locally produced products (Dorresteijn et al. 2015). If these conditions are not met, then the maintenance of appropriate management regimes can still be possible, though they are not going to be sustainable. In several depopulated mountain areas, grasslands are only managed for conservation, and there is no possibility to utilise the cut hay for traditional purposes (Kovács-Hostyánszki et al. 2016). In such cases, its transportation would be economically unsustainable. Applicability and suitability of traditional management should be carefully considered before planning large-scale conservation or restoration projects. The legacies of former degradation (e.g. abandonment) last for a long time, and if there is an interruption in the management, grasslands can return back to a degraded and weed-dominated stage (Kelemen et al. 2014). 


\section{What are the steps necessary for the widespread implementation of sustainable solutions?}

Given the above mentioned challenges and the extensiveness of the area of abandoned grasslands, in many cases it is unfeasible or even impossible to reintroduce the traditional or most appropriate management regimes. In such cases, it is necessary to implement an alternative or surrogate management regime. However, it should be considered that different grassland management regimes affect the selection pressure in grassland species differently (as shown for plants in Pluess 2013). Thus, it is possible that we are unable to achieve the conservation objective via the implementation of an alternative management regime, but at least we can mitigate some of the negative effects of abandonment (Valkó et al. 2014).
In some cases it is possible to decrease the economical costs related to traditional management. This can be achieved by decreasing the frequency of mowing, e.g. mowing in every second or third year (Ryser et al. 1995, Köhler et al. 2005) or implementing spatial mosaic mowing systems (Kleyer 2007, Balázsi 2018, this issue). This spatial or temporal variation in mowing regimes can reduce the economic costs of management, and can also promote higher levels of biodiversity by increasing spatial and temporal environmental heterogeneity (Valkó et al. 2012). Another option is to retain the original management regime, but increasing its cost-effectiveness, such as in the case of the transition from hand mowing to mowing by machinery. However, the more homogeneous sward structure and the compaction that can result from the use of heavy machinery can considerably decrease the grassland conservation values (Schlüter et al. 1990).

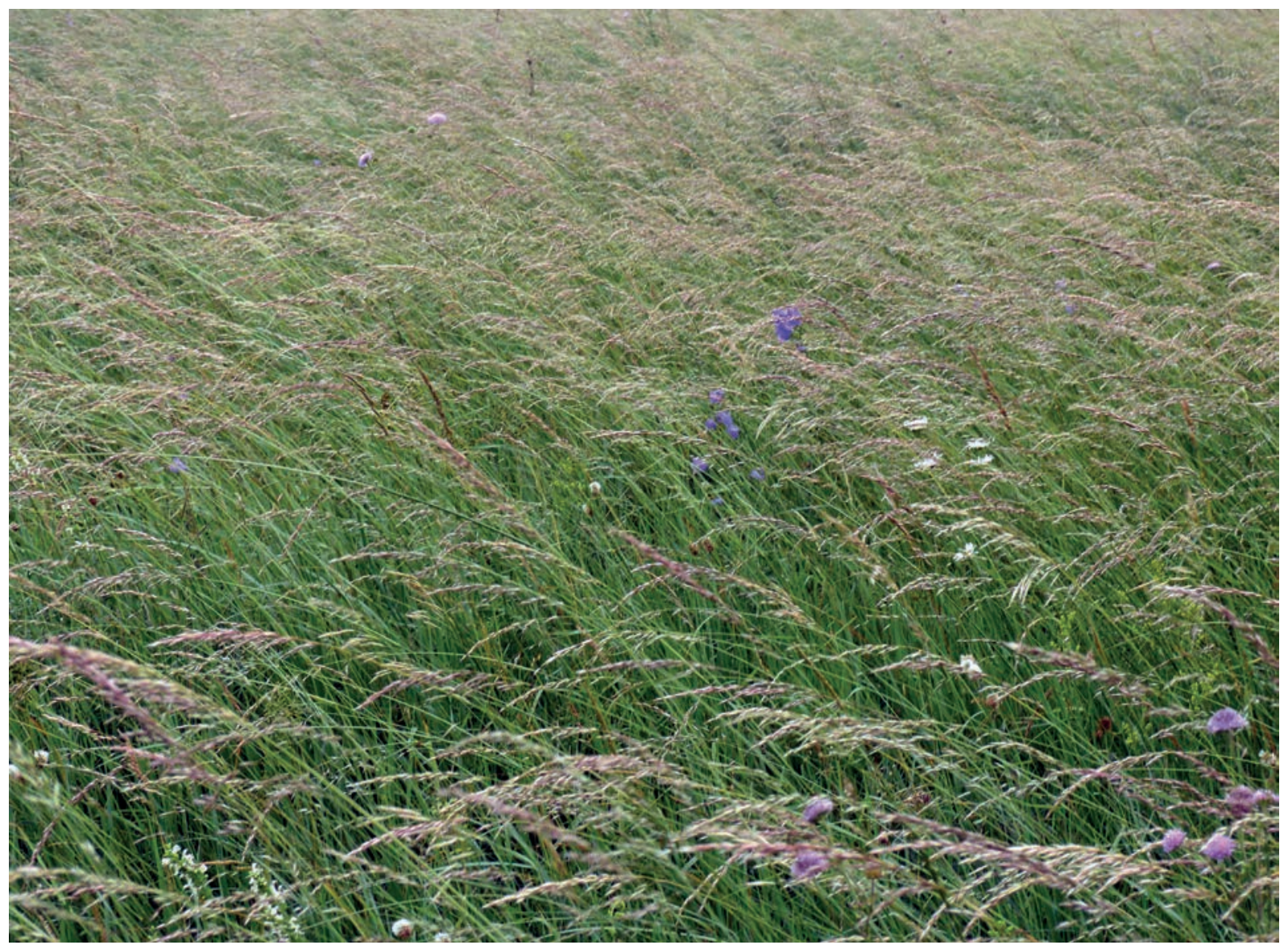

Grassland dominated by Arrhenatherum elatius in the Streletskaya steppe, West-Russia. The species richness of steppes decreased considerably after switching from hand mowing to mowing by heavy machinery. Photo taken in the $11^{\text {th }}$ European Dry Grassland Meeting, near Kursk, Russia by Orsolya Valkó.

Travniki z prevladujočo visoko pahovko (Arrhenatherum elatius) v stepi Streletskaya v zahodni Rusiji. Vrstna pestrost v stepahse je močno zmanjšala po zamenjaviročne košnje s košnjo s težko mehanizacijo. Fotografijo je posnela Orsolya Valkó med 11. srečanjem Evropske skupine za suha travišča pri Kursku v Rusiji. 


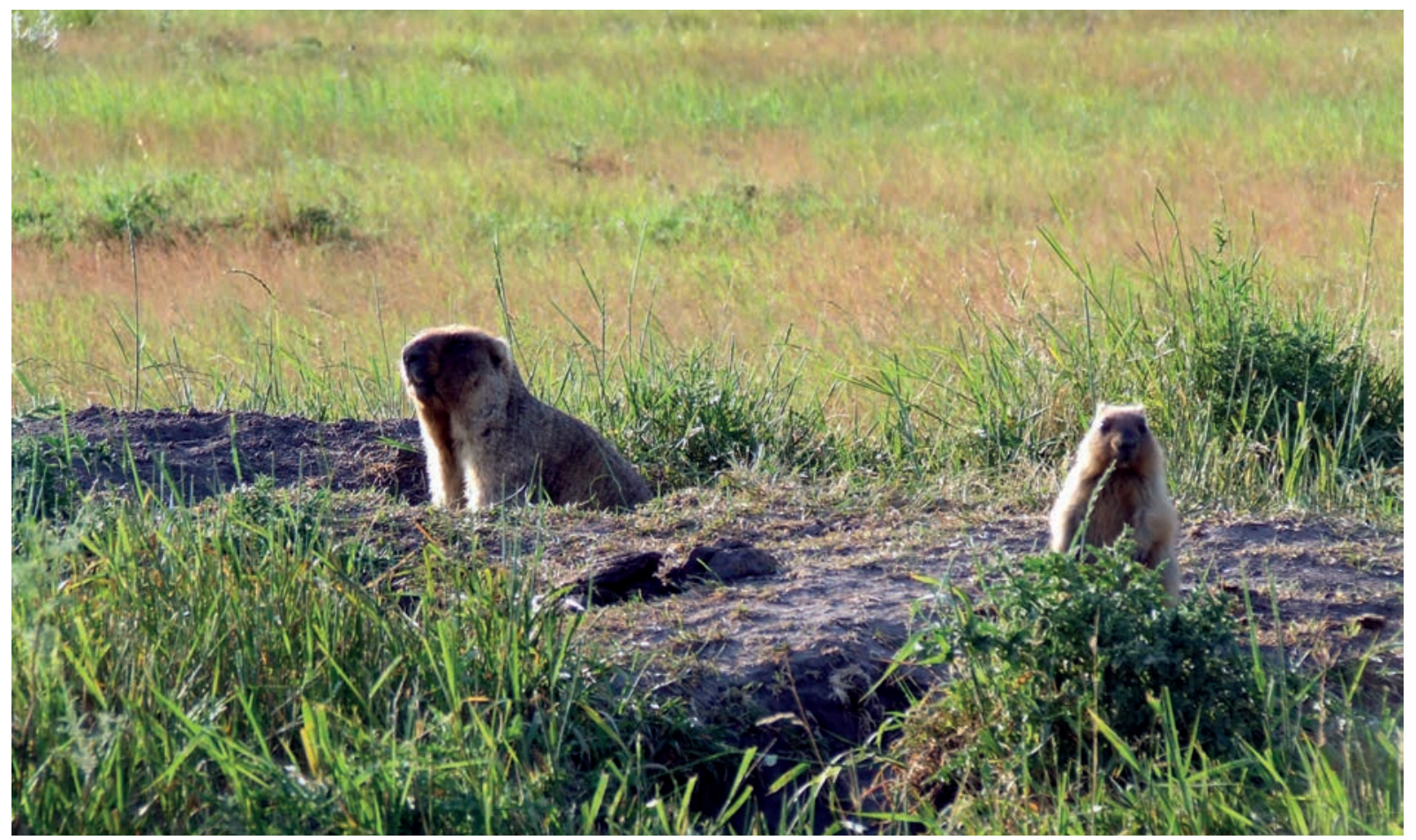

For ensuring proper habitat structure for Steppe Marmots (Marmota bobak), livestock grazing can be replaced by regular and frequent mowing. Photo by Vladimir Ronkin.

Za zagotavljanje primerne habitatne strukture za stepskega svizca (Marmota bobak) lahko nadomestimo pašo živine z redno in pogosto košnjo. Foto Vladimir Ronkin.

In other cases, the reintroduction of former management regimes is impossible. For instance, after sedentarisation, nomadic pastoral culture started to vanish from several parts of the Asian steppes. In combination with climatic and land use changes and lack of adequate water supply, the revitalisation of these nomadic regimes is very unlikely (Kamp et al. 2016, Deák et al. 2018). In the absence of local animal husbandry and grazing, Savchenko \& Ronkin (2018, this issue) applied frequent repeated mowing to mimic the formerly typical disturbance and increase the availability of fresh and green forage for Steppe Marmots. They found that it can be an effective management measure, but it requires strong and consistent dedication and enthusiasm from volunteers to mow the parcels 15-20 times a year.

Mulching, i.e. cutting and chopping the biomass on site is a widely applied alternative to mowing. It is much more cost-effective and usually leads to the development of a similar species composition as mowing (e.g. Köhler et al. 2005, Liira et al. 2009). An alternative cost-effective management regime could be prescribed burning (Valkó et al. 2014). However, there is currently a considerable lack of knowledge regarding the conditions for its application; thus, burning can only be recommended currently for small-scale experimental testing.

\section{How can we ensure the sustainability of grassland management?}

For the long-term maintenance of grassland biodiversity, it is crucial to ensure the viability of management. Projectbased funding schemes make this task quite challenging, since funds are generally available only for a short period of a couple of years. For ensuring sustainability, it is crucial to get local farmers involved and interested in grassland management. For this purpose, agri-environmental subsidy systems can be an option, which provides financial incentives to those who apply good management practices. However given the relative uncertainty and bureaucratic nature of such schemes (Balázsi 2018, this issue), they can be more effective if farmers are not only interested in management because of the paid subsidy, but also because it can support their livelihood in local markets. In regions where grassland management is not sustainable through the generation of a reasonable income from agriculture, it is difficult to justify why grasslands should be managed. For sustainable grassland management, the demands of biodiversity conservation and agriculture need to be harmonise. Of course in the core areas of national parks or biosphere reserves, biodiversity conservation is the primary objective, but in less valuable or privately-owned areas, 
some kind of compromise would support the long-term coexistence of local people and the maintenance of diverse grasslands. Generally, farmers perceive the biodiversity targeted-management of grasslands as a limitation for hay or livestock production, because it generally requires a reduction of inputs and results in a loss of yield compared to intensively managed grasslands (Isselstein et al. 2005). Besides subsidy systems, the ecosystem services provided by grasslands (Lamarque et al. 2011, Kovács-Hostyánszki et al. 2016, Valkó et al. 2016b) should be explained and communicated to the local community (Balázsi 2018, this issue). For the sustainability of grassland management, an effective monitoring system is crucial, which also allows the modification of management regimes if necessary.

Reversing the negative consequences of grassland abandonment is a major challenge for the conservation of grassland biodiversity. In many regions, the biodiversity of species-rich grassland habitats is dependent on the efforts of dwindling numbers of farmers who still use traditional extensive agricultural regimes (Kovács-Hostyánszki et al. 2016). A key driver is the lack of economic sustainability of the ecologically most sustainable solution for grassland management (Abson et al. 2017). Initiatives for the sustainable conservation of semi-natural grasslands need to consider the issues of both social (Dorresteijn et al. 2015) and economic sustainability if they are to succeed in generating an ecologically sustainable solution (Abson et al. 2017).

\section{Motivation of the special feature}

This special feature complements a series of special issues devoted to Palaearctic grasslands (including Habel et al. 2013, Apostolova et al. 2014, Dengler et al. 2014, Janišová et al. 2014, Carboni et al. 2015, Ruprecht et al. 2015, Becker et al. 2016, Török et al. 2016, Valkó et al. 2016c, Deák et al. 2017), edited on behalf of the Eurasian Dry Grassland Group (EDGG, http://www. edgg.org). The present special feature was initiated by members of the EDGG attending the 13th Eurasian Dry Grassland Conference (EDGC) at Sighisoara, Romania in September 2016 (Venn et al. 2018, this issue).

\section{Contributions of the special feature}

This special feature consists of six contributions, from Kazakhstan (Bragina \& Khisametdinova 2018), Romania (Balázsi 2018), Russia and Ukraine (Didukh et al. 2018), Russia (Cherednichenko \& Borodulina 2018, Gracheva et al. 2018), and Ukraine (Savchenko \& Ronkin 2018). These papers cover a wide range of grassland habitats across Eurasia. They focus on the biodiversity values and conservation issues of Palaearctic grasslands.

Savchenko \& Ronkin (2018, this issue) studied the effects of grassland management on a keystone rodent species, the Steppe Marmot (Marmota bobak) in Ukrainian steppes. They revealed that livestock grazing is a crucial factor for maintaining the habitat structure and forage quality favourable for the marmots. They emphasised that the fresh and green biomass re-sprouting after grazing is the preferred food for the marmots, especially in the late summer fattening period. The study draws attention to the importance of grazing, and the relationship between grazing megaherbivores and rodents in the functioning of steppe ecosystems. They also highlighted that due to socio-economic constraints, livestock grazing cannot be introduced into several abandoned steppe regions. As an alternative management of Steppe Marmot habitats, they tested repeated mowing at high-frequency: they mowed small plots 15-20 times per year to provide freshly resprouting green forage for the marmots. They found that, in the absence of livestock grazing, frequent repeated mowing constitutes an alternative measure to maintain suitable habitats for Steppe Marmots.

The dual threats of land abandonment and agricultural intensification change biodiversity patterns not only in the cultural landscapes of Europe, but also in NorthWest Russia, where Cherednichenko and Borodulina (2018, this issue) investigated abandoned and managed grasslands in the Central Forest Reserve. This study emphasizes the importance of these grasslands for the overall biodiversity of the reserve, as almost half of all plant species listed in the reserve occur only there. This paper exemplifies the influence of previous and ongoing management on phytosociological patterns: differences in the management regime not only distinguish four different groups of plant associations, but also influence the presence of red-listed and invasive plants. Even though the meadows surveyed by Cherednichenko and Borodulina (2018, this issue) seem to be intact systems after 25 years of abandonment, species composition and species richness are inevitably facing future changes through natural succession. Additionally, nutrient availability has been shown to result in altered plant species composition and richness, even after many years of application. In combination with other biophysical conditions of the grassland, such long-term effects play an important role for the stability of the system. In order to maintain biodiversity on these grasslands, this paper presents information on the importance of integrating anthropogenic land use and conservation through adequate management regimes. As 


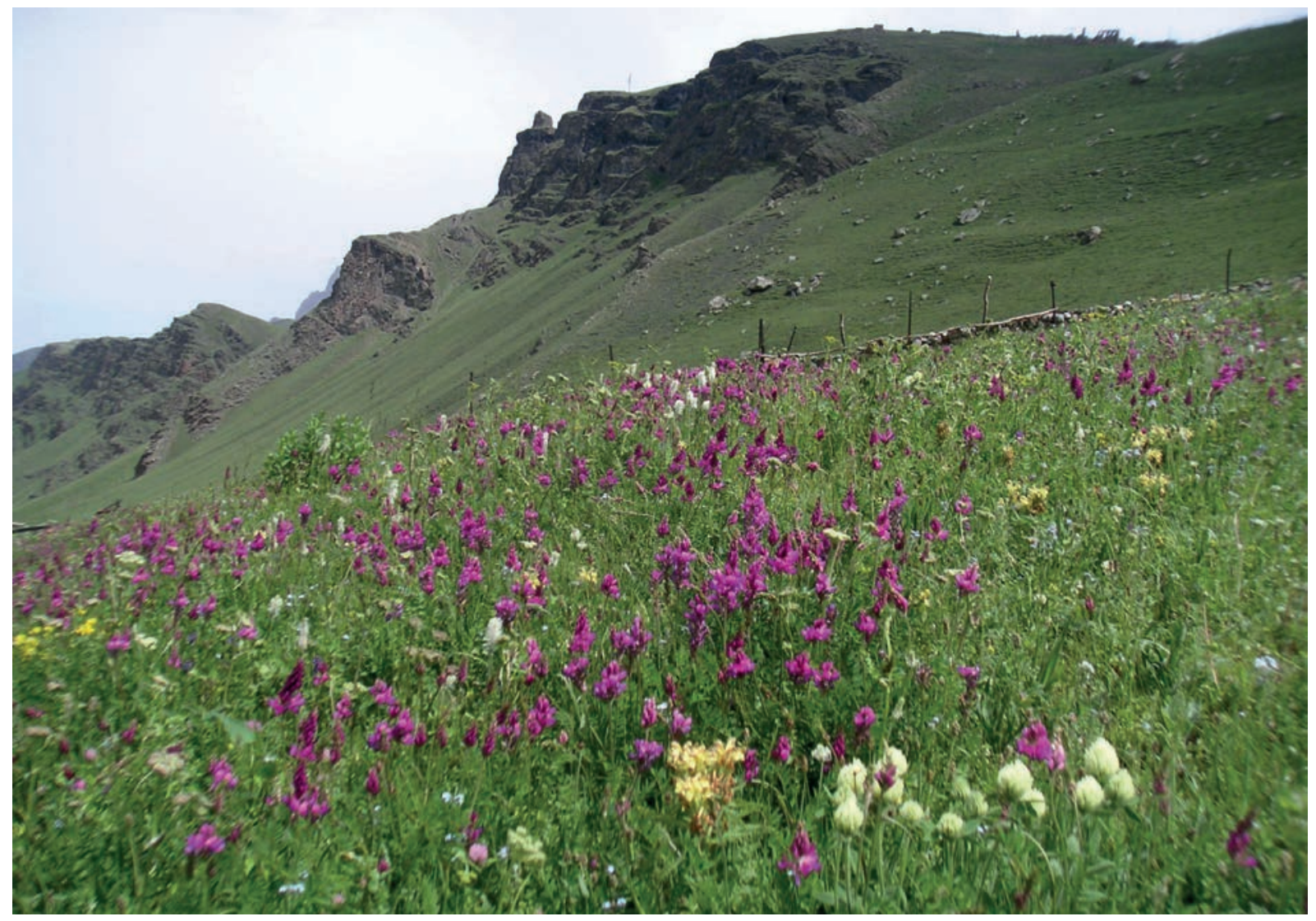

Abandoned hay meadow in the background of the steppe on the eroded slopes of the North Caucasus. Photo by Elena Belonovskaya.

Opuščene senožeti, v ozadju stepa na erodiranih pobočjih severnega Kavkaza. Foto Elena Belonovskaya.

a Biosphere Reserve, the Central Forest Reserve requires attention to the implementation of such regimes.

Terraces are ancient man-made elements of mountainous regions for the purpose of reducing the risk of erosion, retaining water and increasing the surface area that is potentially utilisable for agricultural purposes. Their typical architecture is still a typical feature in such landscapes, however, a considerable proportion of agriculturally used terraces have been abandoned worldwide. The question therefore arises as to whether abandoned terraces contribute to landscape-scale biodiversity conservation in mountainous areas. Gracheva et al. (2018, this issue) studied the vegetation and biodiversity conservation potential of abandoned terraces in the North Caucasus. They found that due to the legacies of past land use, such as the unifying role of soil cultivation and the relatively young age of grasslands, the vegetation composition of various terraces was rather similar. They assume that due to climatic change, i.e. the increase of heat and humidity, climatic differences of the slopes will be reduced, which will lead to the further convergence of the species composition of grasslands.
Balázsi (2018, this issue) summarized the most important issues regarding grassland conservation in Central-Eastern Europe, more specifically in the Czech Republic, Slovakia, Hungary and Romania. The methods of this paper are based on a literature review of papers and documents concerning grassland management in the past, as well as from field visits in several grassland areas in Central-Europe when the author had an opportunity to observe grassland biodiversity and problems related with its conservation. In her paper, Balázsi (2018) reviewed the history of the region from the perspective of management and conservation of grasslands. Collectivisation during the socialism era (i.e. 1945-1989) was the most important change that led to the disappearance of small-scale farming and disconnection of whole rural societies from their land. On the other hand, during this period relatively many protected areas have been established, although their management and administration was largely inadequate. After 1989 the large-scale migration from rural to urban areas began, resulting in further disconnection of people from their land in the countryside. The subsequent privatization of land during this 
period was rapid but mainly occurred in the most productive areas, while unproductive regions suffered from restricted production and land abandonment. Furthermore, due to substantial changes in the land ownership structure (i.e. privatization) management of protected areas became more complicated than it had been prior to 1989. Finally, Balázsi (2018) revised the main current challenges associated with grassland conservation in the four countries since their accession to the European Union. Harmonizing the Natura 2000 network with the existing forms of protection appeared to be the most serious challenge (mainly in Romania and Slovakia and less serious in Hungary and the Czech Republic). There are still gaps between declared policy and practice, mainly resulting from conflicts between nature conservation and profit-oriented agriculture, and the inflexibility of institutions responsible for mediation between these two. But at the same time, new opportunities for grassland conservation became available, such as EU subsidies for conservation. It is important to conclude that, generally, conservation challenges in Central-Eastern Europe are different as compared to those reported for Western Europe. This is mainly due to different land-use history, ownership structure and recent economical and political changes within the region. Thus case studies presented in the paper are valuable for utilization in evidence-based management of grassland biodiversity and can be useful for conservation strategies in the future.
Didukh et al. (2018, this issue) provided a synthesis of the syntaxonomy of the dry grasslands of the order Thymo cretacei-Hyssopetalia cretacei Didukh 1989. These grasslands have developed on chalk outcrops in the southwestern Central Russian Upland and the Donetsk range, and harbour a high diversity of endemic species. They used data from 354 own relevés and 178 published relevés from these vegetation types, and 300 relevés of other xerophytic vegetation types. Data were analysed by the modified TWINSPAN classification. They showed that the order Thymo cretacei-Hyssopetalia cretacei includes twelve associations belonging to three alliances: Artemisio hololeucae-Hyssopion cretacei Romashchenko et al. 1996, Euphorbio cretophilae-Thymion cretacei Didukh 1989 and Centaureo carbonatae-Koelerion talievii Romashchenko et al. 1996. The work of Didukh et al. (2018) can serve as an important reference for studies and conservation plans targeting this unique vegetation type.

Bragina \& Khisametdinova (2018, this issue) presented an investigation into the woodlouse fauna (Isopoda: Oniscidea) of steppe habitats in Kazakhstan. They sampled the fauna of a variety of habitats and vegetation complexes. They recorded six species, of which four were recorded for the first time in Kazakhstan. This brought the total number of known species for the country to 16 . This paper also provides information of the habitat preferences of the recorded species, the locations where they were recorded and information on their distribution.

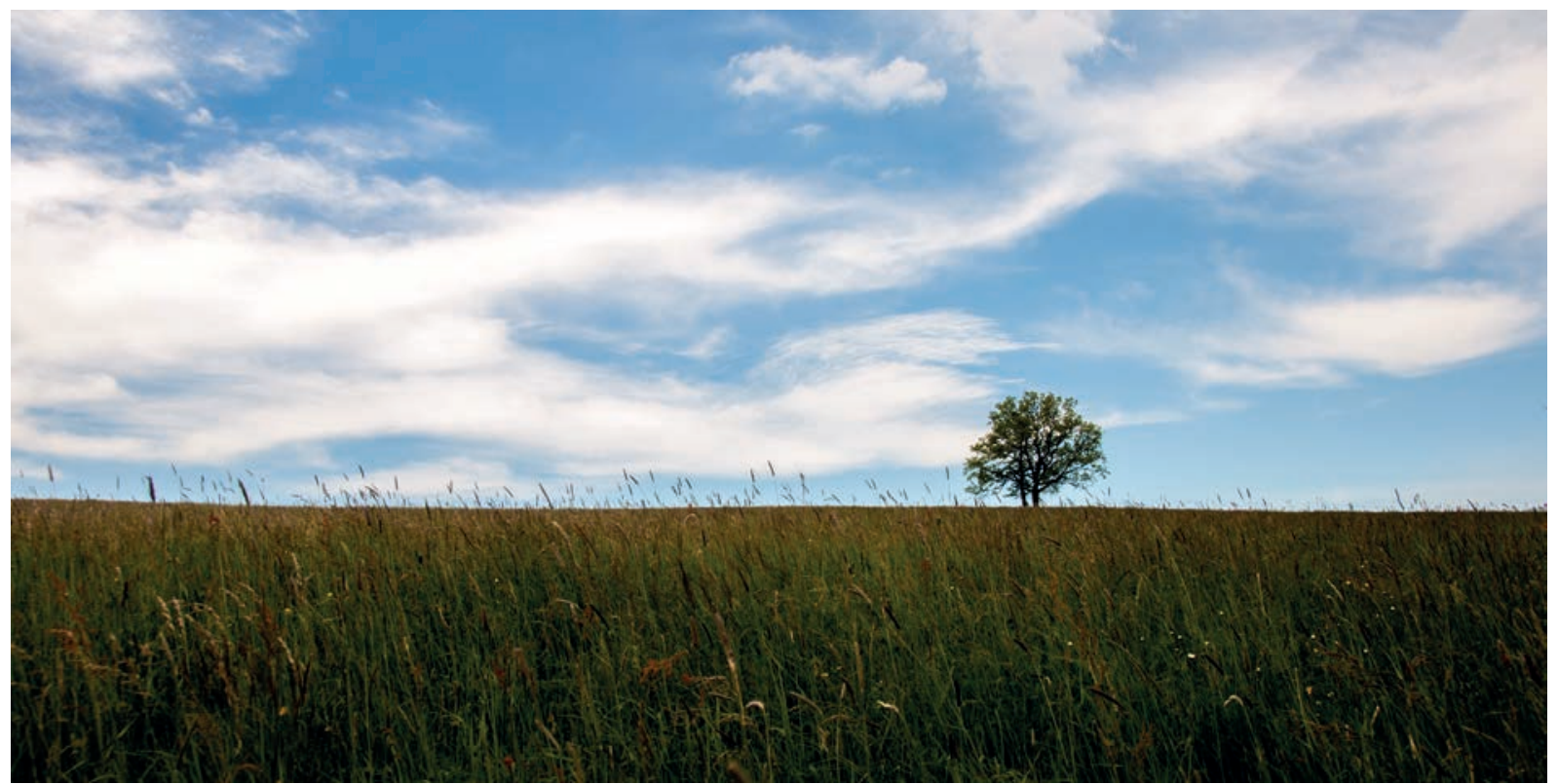

Long-term monitoring of species-rich hay meadows of the White Carpathians Protected Landscape Area represents the key feedback element of a successful conservation or/and restoration of grasslands. Photo by Ágnes Balázsi.

Dolgotrajni monitoring vrstno bogatih senožeti v Krajinskem parku Beli Karpati predstavlja ključne povratne informacije o uspešnosti ohranjanja in/ali obnavljanja travišč. Foto Ágnes Balázsi. 


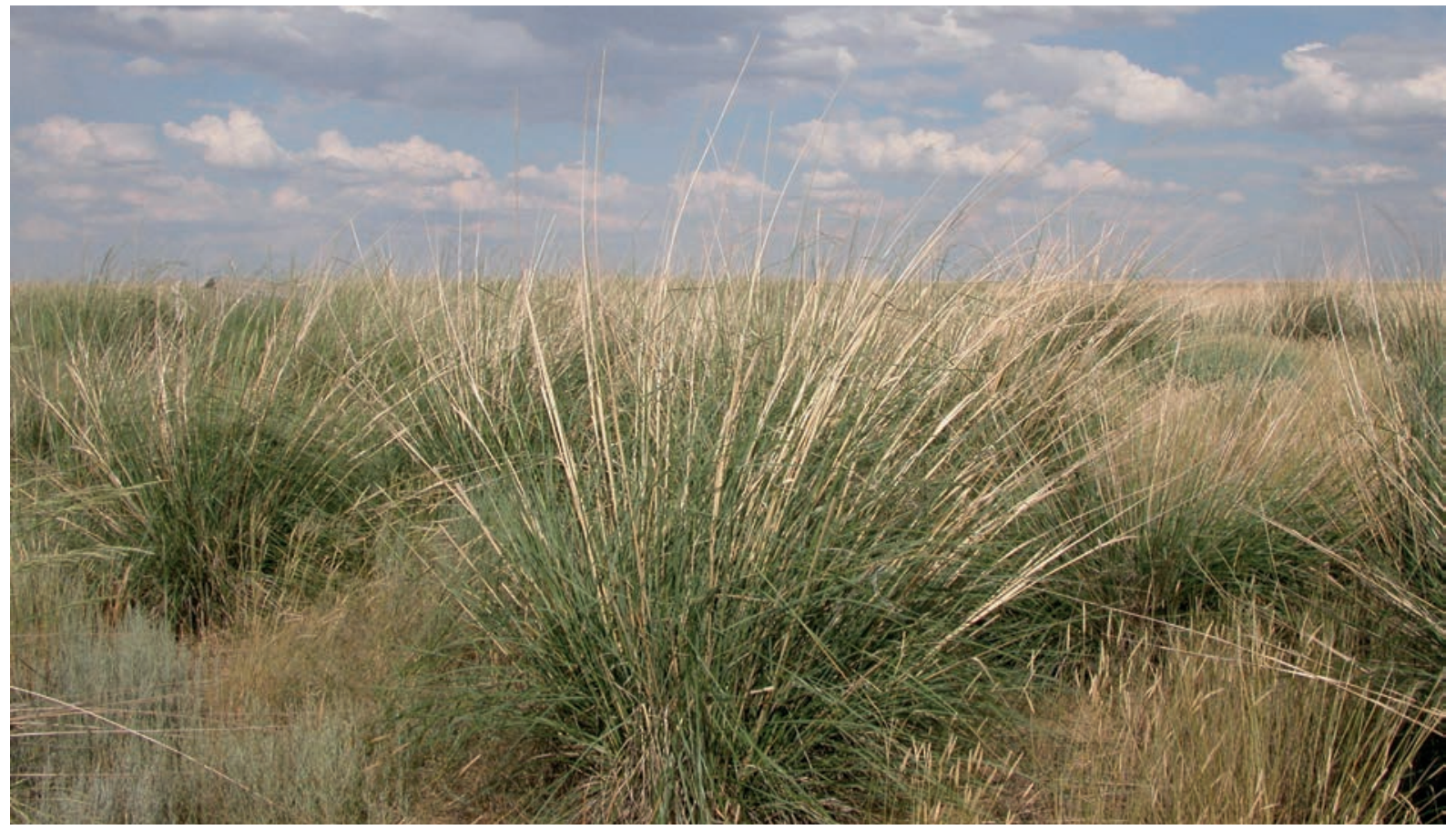

Feathergrass steppe in the Naurzum National Nature Reserve in Kazakhstan. Photo by Tatyana M. Bragina.

Stepa z bodalicami v Narodnem naravnem rezervatu Naurzum v Kazahstanu. Foto Tatyana M. Bragina.

\section{Conclusions}

This Special Feature focuses on the biodiversity values of Palaearctic grasslands, with an emphasis on the challenge of their abandonment. We show that abandonment represents a major threat for grasslands in many regions and due to the substantial socio-economic changes, the reintroduction of the traditional management is generally no longer sustainable. Papers in the Special Feature highlight that the implementation of a sustainability perspective might be able to integrate social and economic, as well as ecological needs, into the planning of grassland management to ensure the long-term and effective conservation of these valuable habitats and their rich biodiversity.

\section{Acknowledgements}

We are grateful to all Authors for their contributions in this special feature and to all the Reviewers for their considerable input of time and effort. We are especially grateful to Aiko Huckauf, for his professional linguistic editing and the courtesy of the Eurasian Dry Grassland Group for financial support. O.V. was funded by NKFI FK 124404 and NKFI KH 126476 grants, the ÚNKP17-4-III-DE-151 grant and the Bolyai János Research Fellowship of the HAS during manuscript preparation.

\section{References}

Abson, D.J., Fischer, J., Leventon, J., Newig, J., Schomerus, T., Vilsmaier, U., von Wehrden, H., Abernethy, P., Ives, C.D., Jager, N.W. \& Lang, D.J. 2017: Leverage points for sustainability transformation. Ambio 46: 30-39.

Apostolova, I., Dengler, J., Di Pietro, R., Gavilán, R. \& Tsiripidis, I. 2014: Dry grasslands of Southern Europe: Syntaxonomy, management and conservation. Hacquetia 13: 5-18.

Auffret, A.G. 2011: Can seed dispersal by human activity play a useful role for the conservation of European grasslands? Applied Vegetation Science 14: 291-303.

Babai, D. \& Molnár, Z. 2014: Small-scale traditional management of highly species-rich grasslands in the Carpathians. Agriculture, Ecosystems \& Environment 182: 123-130.

Bakker, J.P. 1998: The impact of grazing on plant communities. In: Grazing and Conservation Management (Ed.: Wallis De Vries, M.F., Bakker, J.P., van Wieren, S.E.), pp. 137-84. Kluwer Academic Publishers, Dordrecht.

Balázsi, Á. 2018: Grassland management in protected areas - Implementation of the EU Biodiversity Strategy in certain post-communist countries. Hacquetia 17: 73-84.

Becker, T., Csecserits, A., Deák, B., Janišová, M., Sutcliffe, L. \& Wagner, V. 2016: Different approaches in grassland analysis - Editorial to the 11th EDGG Grassland Special Feature. Tuexenia 36: 287-291.

Bekker, R.M., Verweij, G.L., Smith, R.E.N., Reine, R., Bakker, J.P., \& Schneider, S. 1997: Soil seed banks in European grasslands: Does land use affect regeneration perspectives? Journal of Applied Ecology 34: $1293-1310$. 
Bonanomi, G., Caporaso, S. \& Allegrezza, M. 2006: Short-term effects of nitrogen enrichment, litter removal and cutting on a Mediterranean grassland. Acta Oecologica 30: 419-425.

Bragina, T. M. \& Khisametdinova, D.D. 2018: The woodlouse (Isopoda: Oniscidea) fauna of steppe habitats in the Kostanay region of Kazakhstan. Hacquetia 17: 111-119.

Brinkert,A.,Hölzel, N., Sidorova, T. \& Kamp,J.2016:Spontaneoussteppe restoration on abandoned cropland in Kazakhstan: Grazing determines successional pathways. Biodiversity \& Conservation 25: 2543-2561.

Carboni, M., Dengler, J., Mantilla-Contreras, J., Venn, S. \& Török, P. 2015: Conservation value, management and restoration of Europe's semi-natural open landscapes. Hacquetia 14: 5-17.

Cherednichenko, O. \& Borodulina, V. 2018: Biodiversity of herbaceous vegetation in abandoned and managed sites under protection regime: A case study in the Central Forest Reserve, NW Russia. Hacquetia 17: 35-60.

Connell, J.H. 1978: Diversity in tropical rain forests and coral reefs. Science 199: 1302-1310.

Cousins, S.A.O. 2009: Extinction debt in fragmented grasslands: Paid or not? Journal of Vegetation Science 20(1): 3-7.

Deák, B., Valkó, O., Kelemen, A., Török, P. Miglécz, T., Ölvedi, T., Lengyel, S. \& Tóthmérész, B. 2011: Litter and graminoid biomass accumulation suppresses weedy forbs in grassland restoration. Plant Biosystems 145: 730-737.

Deák, B., Tölgyesi, C., Kelemen, A., Bátori, Z., Gallé, R., Bragina, T.M., Abil, Y.A. \& Valkó, O. 2018: Vegetation of steppic cultural heritage sites in Kazakhstan - Effects of microhabitats and grazing intensity. Plant Ecology \& Diversity doi: $10.1080 / 17550874.2018 .1430871$

Deák, B., Wagner, V., Csecserits, A. \& Becker, T. 2017: Vegetation and conservation of Central-European grasslands - Editorial to the 12th EDGG Special Feature. Tuexenia 37: 375-378.

Deák, B., Valkó, O., Török, P. \& Tóthmérész, B. 2016a: Factors threatening grassland specialist plants - A multi-proxy study on the vegetation of isolated grasslands. Biological Conservation 204: $255-262$.

Deák, B., Tóthmérész, B., Valkó, O., Sudnik-Wójcikowska, B., Bragina, T.-M., Moysiyenko, I., Apostolova, I., Bykov, N., Dembicz, I. \& Török, P. 2016b: Cultural monuments and nature conservation: The role of kurgans in maintaining steppe vegetation. Biodiversity \& Conservation 25: 2473-2490.

Deák, B., Valkó, O., Török, P., Végvári, Z., Schmotzer, A., Kapocsi, I. \& Tóthmérész, B. 2014: Grassland fires in Hungary - A problem or a potential alternative management tool? Applied Ecology \& Environmental Research 12: 267-283.

Dengler, J., Janišová, M., Török, P. \& Wellstein, C. 2014: Biodiversity of Palaearctic grasslands: a synthesis. Agriculture Ecosystems and Environment 182: 1-14.

Didukh, V., Chusova, O. \& Demina, O. 2018: Syntaxonomy of chalk outcrops vegetation of the Thymo cretacei-Hyssopetalia cretacei order. Hacquetia 17: 85-110.

Diemer, M., Oetiker, K. \& Billeter, R. 2001: Abandonment alters community composition and canopy structure of Swiss calcareous fens. Applied Vegetation Science 4: 237-246.

Dorresteijn, I., Loos, J., Hanspach, J. \& Fischer J. 2015: Socioecological drivers facilitating biodiversity conservation in traditional farming landscapes. Ecosystem Health and Sustainability 1(8):28. http:// dx.doi.org/10.1890/EHS15-0021.1

Eckstein, R.L. \& Donath, T.W. 2005: Interactions between litter and water availability affect seedling emergence in four familiar pairs of floodplain species. Journal of Ecology 93: 807-816.

European Commission (1992) Council Directive 92/43/EEC of 21 May 1992 on the conservation of natural habitats and of wild fauna and flora.

Gazol, A., Tamme, R., Takkis, K., Kasari, L., Saar, L., Helm, A. \& Pärtel, M. 2012: Landscape- and small-scale determinants of grassland species diversity: Direct and indirect influences. Ecography 35: 944-951.

Gracheva, R., Belonovskaya, E. \& Vinogradova, V. 2018: Mountain grassland ecosystems on abandoned agricultural terraces (Russia, North Caucasus). Hacquetia 17: 61-72.

Habel, J. C., Dengler, J., Janišová, M., Török, P., Wellstein, C. \& Wiezik, M. 2013: European grassland ecosystems: Threatened hotspots of biodiversity. Biodiversity \& Conservation 22: 2131-2138.

Halada, L., David, S.,Hreško, J., Klimantová, A., Bača, A., Rusňák, T., Bural', M. \& Vadel, L. 2017: Changes in grassland management and plant diversity in a marginal region of the Carpathian Mts. in 1999-2015. Science of the Total Environment 609: 896-905.

Halada, L., Evans, D., Romão, C., \& Petersen, J. E. 2011: Which habitats of European importance depend on agricultural practices? Biodiversity \& Conservation 20(11): 2365-2378.

Hansson, M.\& Fogelfors, H. 2000: Management of a semi-natural grassland; results from a 15-year-old experiment in southern Sweden. Journal of Vegetation Science 11:31-38.

Helm, A., Hanski, I. \& Pärtel, M. 2006: Slow response of plant species richness to habitat loss and fragmentation. Ecology Letters 9: 72-77.

Humbert, J.-Y., Pellet, J., Buri, P. \& Arlettaz, R. 2012. Does delaying the first mowing date benefit biodiversity in meadowland? Environmental Evidence 1: 9.

Humbert, J.-Y., Ghazoul, J. \& Walter, T. 2009: Meadow harvesting techniques and their impacts on field fauna. Agriculture, Ecosystems and Environment 130: 1-8.

Isselstein, J., Jeangros, B. \& Pavlů, V. 2005: Agronomic aspects of biodiversity targeted management of temperate grasslands in Europe A review. Agronomy Research 3: 139-151.

Janišová, M., Boch, S., Ruprecht, E., Reitalu, T. \& Becker, T. 2014: Continental dry grasslands from range margin to range centre - Editorial to the 9th Dry Grassland Special Feature. Tuexenia 34: 347-353.

Janssen, J.A.M., Rodwell, J.S., García Criado, M., Gubbay, S., Haynes, T., Nieto, A., Sanders, N., Landucci, F., Loidi, J., (...) \& Gubbay, S. 2016: European Red List of Habitats Part 2. Terrestrial and freshwater habitats. European Commission, Publications Office of the European Union, Luxembourg.

Kamp, J., Koshkin, M.A., Bragina, T.M., Katzner, T.E., MilnerGulland, E.J., Schreiber, E., Sheldon, R., Shmalenko, A., Smelansky, I., Terraube, J. \& Urazaliev, R. 2016: Persistent and novel threats to the biodiversity of Kazakhstan's steppes and semi-deserts. Biodiversity \& Conservation 25:2521-2541.

Kelemen, A., Török, P., Valkó, O., Miglécz, T. \& Tóthmérész, B. 2013a: Mechanisms shaping plant biomass and species richness: plant strategies and litter effect in alkali and loess grasslands. Journal of Vegetation Science 24: 1195-1203. 
Kelemen, A., Török, P., Valkó, O., Deák, B., Miglécz, T., Tóth, K., Ölvedi, T. \& Tóthmérész, B. 2014: Sustaining recovered grasslands is not likely without proper management: vegetation changes and large-scale evidences after cessation of mowing. Biodiversity and Conservation 23: 741-751.

Kleyer, M. 2007: Mosaic cycles and conservation management. Basic and Applied Ecology 8: 293-294.

Köhler, B., Gigon, A., Edwards, P.J., Krüsi, B., Langenauer, R., Lüscher, A. \& Ryser, P. 2005: Changes in the species composition and conservation value of limestone grasslands in Northern Switzerland after 22 years of contrasting managements. Perspectives in Plant Ecology, Evolution and Systematics 7: 51-67.

Kovács-Hostyánszki, A., Földesi, R., Mózes, E., Szirák, Á., Fischer, J., Hanspach, J \& Báldi, A. 2016: Conservation of Pollinators in Traditional Agricultural Landscapes - New Challenges in Transylvania (Romania) Posed by EU Accession and Recommendations for Future Research PLoS ONE 11(6):e0151650

Kuussaari, M., Bommarco, R., Heikkinen, R. K., Helm, A., Krauss, J., Lindborg, R., Öckinger, E., Pärtel, M., Pino, J., Rodà, F., Stefanescu, C., Teder, T., Zobel, M., \& Stefanescu, C. 2009: Extinction debt: A challenge for biodiversity conservation. Trends in Ecology \& Evolution 24(10): 564-571.

Lamarque, P., Tappeiner, U., Turner, C., Steinbacher, M., Bardgett, R. D., Szukics, U., Schermer, M. \& Lavorel, S. 2011: Stakeholder perceptions of grassland ecosystem services in relation to knowledge on soil fertility and biodiversity. Regional Environmental Change 11(4): 791-804.

Leuschner, C. \& Ellenberg, H. 2017: Ecology of Central European Non-Forest Vegetation: Coastal to Alpine, Natural to Man-Made Habitats: Vegetation Ecology of Central Europe (Vol. 2). Springer.

Liira, J., Issak, M., Jögar, Ü., Mändoja, M. \& Zobel, M. 2009: Restoration management of a floodplain meadow and its costeffectiveness - The results of a 6-year experiment. Annales Botanici Fennici 46: 397-408.

MacDougall, A.S. \& Turkington, R. 2007: Does the type of disturbance matter when restoring disturbance-dependent grasslands? Restoration Ecology 15: 263-272.

Öckinger, E., Eriksson, A. K. \& Smith, H. G. 2006: Effects of grassland abandonment, restoration and management on butterflies and vascular plants. Biological Conservation 133(3): 291-300.

Parr, T.W. \& Way, J.M. 1988: Management of roadside vegetation: The long-term effects of cutting. Journal of Applied Ecology 25: 1073-1087.

Pluess, A.R. 2013: Meta-analysis reveals microevolution in grassland plant species under contrasting management. Biodiversity and Conservation 22(10): 2375-2400.

Poschlod, P. \& WallisDeVries, M.F. 2002: The historical and socioeconomic perspective of calcareous grasslands: lessons from the distant and recent past. Biological Conservation 104:361-376.

Pykäla, J. 2001: Mitigating human effects on European biodiversity through traditional animal husbandry. Conservation Biology 14: $705-712$.

Ruprecht, E., Janišová, M., Sutcliffe, L., Boch, S. \& Becker, T. 2015: Dry grasslands of Central-Eastern and South-Eastern Europe shaped by environmental heterogeneity and human land use - Editorial to the 10th Dry Grassland Special Feature. Tuexenia 35: 321-328.
Ryser, P., Langenauer, R. \& Gigon, A. 1995: Species richness and vegetation structure in a limestone grassland after 15 years of management with six biomass removal regimes. Folia Geobotanica et Phytotaxonomica. 30: 157-167.

Savchenko, G. \& Ronkin, V. 2018: Grazing, abandonment and frequent mowing influence persistence of Steppe Marmot, Marmota bobak. Hacquetia 17: 25-34.

Schlüter, H., Böttcher, W., \& Bastian, O. 1990: Vegetation change caused by land-use intensification - Examples from the Hilly Country of Saxony. Geo Journal 22(2): 167-174.

Tälle, M., Deák, B., Poschlod, P., Valkó, O., Westerberg, L.\& Milberg, P. 2016: Grazing vs. mowing: a meta-analysis of biodiversity benefits for grassland management. Agriculture, Ecosystems \& Environment 15: 200-212.

Tälle, M., Bergman, K.O., Paltto, H., Pihlgren, A., Svensson, R., Westerberg, L., Wissman, J. \& Milberg, P. 2014: Mowing for biodiversity: grass trimmer and knife mower perform equally well. Biodiversity \& Conservation 23: 3073-3089.

Török, P., Wesche, K., Ambarl1, D., Kamp, J. \& Dengler, J. 2016: Step(pe) up! Raising the profile of the Palaearctic natural grasslands. Biodiversity \& Conservation 25: 2187-2195.

Tóth, E., Deák, B., Valkó, O., Kelemen, A., Miglécz, T., Tóthmérész, B. \& Török, P. 2016: Livestock type is more crucial than grazing intensity: Traditional cattle and sheep grazing in short-grass steppes. Land Degradation \& Development doi: 10.1002/ldr.2514.

Valkó, O., Deák, B., Török, P., Kirmer, A., Tishew, S., Kelemen, A., Tóth, K., Miglécz, T., Radócz, S., Sonkoly, J., Tóth, E., Kiss, R., Kapocsi, I. \& Tóthmérész, B. 2016a: High-diversity sowing in establishment gaps: A promising new tool for enhancing grassland biodiversity. Tuexenia 36: 359-378.

Valkó, O., Deák, B., Török, P., Kelemen, A., Miglécz, T., Tóth, K. \& Tóthmérész, B. 2016b: Abandonment of croplands: problem or chance for grassland restoration? Case studies from Hungary. Ecosystem Health and Sustainability 2(2): e01208.

Valkó, O., Zmihorski, M., Biurrun, I., Loos, J., Labadessa, R. \& Venn, S. 2016c: Ecology and conservation of steppes and seminatural grasslands. Hacquetia 15: 5-14.

Valkó, O., Török, P., Matus, G. \& Tóthmérész, B. 2012: Is regular mowing the most appropriate and cost-effective management maintaining diversity and biomass of target forbs in mountain hay meadows? Flora 207: 303-309.

Valkó, O., Török, P., Tóthmérész, B. \& Matus, G. 2011: Restoration potential in seed banks of acidic fen and dry-mesophilous meadows: Can restoration be based on local seed banks? Restoration Ecology 19: $9-15$.

Valkó, O., Török, P., Deák, B. \& Tóthmérész, B. 2014: Review: Prospects and limitations of prescribed burning as a management tool in European grasslands. Basic and Applied Ecology 15: 26-33.

Venn et al. 2018: The Eurasian Dry Grassland Group (EDGG) in 2016-2017. Hacquetia, 17: 17-24.

WallisDeVries, M.F., Poschlod, P. \& Willems, J.H. 2002: Challenges for the conservation of calcareous grasslands in northwestern Europe: Integrating the requirements of flora and fauna. Biological Conservation 104: 265-273. 